\title{
What is the Effect of Using Language Arts Workstations in Success and Retention Rates in Spanish College Classes?
}

\author{
Yesenia Chavez, Ph.D. \\ San Jacinto College-Central \\ 8060 Spencer Hwy, Pasadena, TX 77505 \\ USA
}

\begin{abstract}
Literacy workstations in language arts classes have been used for at least two decades in grades K-12 as valuable teaching resources, but their implementation is more limited at the college level (Chavez, 2019a). Currently, there is more research at the elementary classroom, followed by middle school, high school and college level. There is also some research about workstations in the job place. However, there is still debate on whether or not language arts workstations are helpful or not in language classes (Hampton et. al, 2015; Reese, 2011). This work supports the first theory and provides a guide of how to create Spanish language arts workstations. The workstations included use the four modes of language: listening, speaking, reading and writing as recommended by Carreira (2012). The results support a correlation between workstations and high academic success rate and high attendance rate among other results.
\end{abstract}

Keywords: Teaching, workstations, literacy centers, literacy workstations, Spanish, Spanish teaching, cooperative learning, language arts

\section{Introduction}

Previous research demonstrates that students of Spanish as a Heritage Language Learners (HLL) or bilingual students may have a higher Spanish vocabulary level than students of Spanish as a Second Language (L2) or Foreign Language (FL) students. Research also found out that the Spanish vocabulary level may be correlated to reading comprehension (Chavez, 2017a; Velasquez, 2015). In other words, the more Spanish vocabulary the students know the better reading comprehension levels in the target language they will have. Therefore, one of the aims of our Spanish classes is to increase the vocabulary level of our students to aide with reading, listening, speaking and writing skills.

Furthermore, literacy workstations in language arts classes have been used for decades in grades K-12 as valuable teaching resources, but their implementation is more limited at the college level (Chavez, 2019a). Currently, there is more research at the elementary classroom, followed by middle school, high school and college level. There is also some research about workstation in the job place. However, there is still debate on whether or not language workstations are helpful or not in language classes (Hampton et. al, 2015; Reese, 2011). This work supports the first theory.

\section{Previous research}

A literacy center or language arts workstation is a space or area specifically designed to improve or practice a specific objective in learning. A language arts workstation or literacy center can be movable or stationary. Please note that those terms are used interchangeable in this work. Some previous research support the use of language arts workstations as they may help to improve the reading and comprehension skills, the language arts skills, the social and writing skills and they may help to improve higher order thinking skills (ReadingRocket.org, 2019).

According to Hilberg et. al. (2003) activity centers or literacy workstations may permit teachers to give instruction and assistance to small groups, provide context for teaching, promote excellence in academics and they may provide justice and incorporation. Workstations should not be too easy or too complicated to be successful. Abou-Sayed (2011) believes that workstations and small group work may help in the following ways to students: they may provide individualized and meaningful instruction, they may provide immediate feedback, they may help to evaluate student progress and they may also improve reading comprehension skills and listening skills.

Chavez (2019a) found out that language arts workstations at the college level give students more time to work one on one with the professor; they help them to improve their leadership skills and they support language learning. In addition, they also help with academic success rate or getting more A's and B's in classes, they could make learning fun, they 
may help students to improve their social and academic skills and they may contribute to improve the student's participation and attendance rate.

Finally, workstations may also save time for the professor when they are implemented correctly. Chavez (2019a) gave some possible explanations for positive results on language arts workstations in college Spanish classes:

2.1 Previous research on Spanish lexicon

2.2 Vocabulary and workstations

2.3 Use of mini lessons by the instructor

2.4 Use of teaching strategies for mixed classes

2.5 Instructor experience

2.6 Small classes (6-25 students)

2.7 The outstanding and diverse student' population, faculty, administrators, curriculum, textbook, college and language diversity on the college

Literacy workstations may have different goals. According to WEC (2019) workstations may reinforce previous learned material, they may aid with teacher interventions, they may allow students to make decisions, they may allow students to work at their own pace and they may help student to learn to work individually or with a classmate. Language arts workstations may include hands on activities and they could make students feel successful on their learning. Fishcher (2019) considers that workstations may help with learning differentiation, help to understand a topic better, help students to engage in different learning tasks, they may help students to have more language exposure, and workstations may expose students to more variety of learning experiences.

\section{Opposition on language arts workstations}

There is also some opposition about the use of language arts workstations as stated in Chavez (2019a). Research is still limited regarding workstations, many of the research is based on teacher' observations, researcher observations, and participant observations especially at the elementary level. More research is needed that is scientific with bigger number of participants and at more levels. Second, workstations can be time consuming for the professor, they could be expensive, they may need departmental approval before they are implemented, they could take more time with bigger classes and the professor may need to create extra activities for the super achiever or gifted students. Finally, in some classes observed, some students did not participate actively, they interrupted the teacher or evaded work especially at the lower levels (Worthy et al. 2015).

Parra (2017) and Deussen (2008) consider that teachers or professors need to be trained for language arts workstations to work successfully. Parra (2017) also states that the more the professors know the better the support they provide to the students. If you have students of Spanish as a Second Language (L2) or Students of Spanish as a Heritage Language (HLLs) you need to be able to select the right materials and teaching methodologies as some students may benefit from explicit teaching and others from implicit teaching (Chavez, 2017a).Beaudrie and Fairclough (2012) also believe in specialized instruction for HLLs students. Deussen (2008) considers that teachers should be familiar with the principles related to teaching the ELLs. Therefore, teachers need to be trained about workstations and that language arts workstations should be evaluated rigorously to make sure they are meeting their purpose or the objectives for their creation. We hope this work can guide the educators to accomplish that goal.

\section{Methodology}

In this study, three mixed Spanish beginning classes participated in a two-year college. Two classes used four Spanish language workstations using the four modes of language: listening, speaking, reading and writing at the college level as recommended by Chavez (2019a) and Carreira (2012). Each portable workstation took in average 7 to 10 minutes and they moved in a clockwise direction. The study also included three surveys: a lexical survey multiple choice, a cloze test vocabulary survey or fill in the blanks and a workstations survey. The lexical surveys were adapted from Chavez (2017a). The first administration was done at the beginning of the semester and the second one was done at the end of the semester. There were 36 participants ages 18 and older. The classes that participated were three hybrid Mixedbeginning classes of Spanish participated in the research (students of Heritage Language (HL) and Students of Spanish as a Second Language (L2). The control group class was the third class without the use of workstations at all but they completed the workstation survey and the lexical surveys.

\section{Results}

It is important to note that for pretest 36 participated and for the posttest, only 32 students participated. However, some surveys had to be eliminated due to being incomplete. Overall, the students in the classes using the language arts workstations had better attendance rate and better success rate with more A's and passing scores than the class control 
group without workstations. The results are similar to previous research (Chavez, 2019a). The vocabulary increase overall was 8 percent or about 400 words.

In the lexical survey pretest 1 the lowest score was 330 words and the highest score was 4000 . In the post test lexical survey 1 the lowest score was a 1000 words and the highest score was 47000 . Therefore, the students in class learned at least 600-700 new vocabulary words during the semester.

Regarding attendance and academic success, we also found the following information:

5.1The more absences a class had the more FX. An FX grade is a failing grade due to absences.

5.2The bigger the class size, the more absences it will have.

5.3The better the attendance rate a class has, the class will have more A's and B's or better academic success rate than classes with low attendance rate. This result is similar to previous research (Chavez, 2019a; Chavez, 2017a).

5.4Attendance and/or workstations, affect the minimum value of the total average grade, the maximum value, the range, the average and the standard deviation and the variance value of the classes included in the present research.

5.5They give time to students more time to work one on one with the professor

5.6They help to improve the students' leadership skills

\subsection{They also support language learning}

However, no important difference was found in the total median grade in the classes with workstations and the class without the workstations. Regarding the social skills in the workstations survey, 50 percent of the students stated that they improved their social skills and self-teem skills. In addition, 19 percent stated that they became more responsible of their own learning and 32 percent of students stated that they got a less intimidating environment. In addition, 16 percent stated that workstations helped them to improve their vocabulary learning and 13 percent stated that workstations helped them to improve their leadership skills. They chose the best workstations to be listening with 40 percent, oral workstations was second with 28 percent, writing 19 percent and the less liked one was speaking. Finally, 76 percent of students identified themselves as student's learners of Spanish as a Second Language (L2). For more detailed and specific results, see figures on Tables and Figures section on figures 1 to 9 at the end of this article.

\section{Process to create language arts workstations}

As the process to create workstations is infinitive, here are some recommendations to create them. The groups can be by ability, heterogeneously or by interest. They also need to be pertinent and have a purpose. The groups should be small of 2 to 4 persons. (Chavez, 2019a; ReadingRockeckts.org, 2019; Abou-Sayed, 2011).As Spanish language arts has four modes of language we also we also recommend four language arts workstations or literacy centers as recommended by Carreira (2012). Those are listening, speaking, reading and writing. Once you decide on which one you want to start first, you got your curriculum ready and or your lesson plans, you are ready for the next step. Decide what is your goal for the workstation you want to create as well as the product. This is the most important step in creating a workstation.

Then, create simple and clear directions on one single page. It is better to give the students more information to prevent interruptions. However, for small children in elementary classroom that still cannot read, you may need to give them the directions orally before you send them to work in the workstations. You may also meet with the leaders of the workstations to make sure they understand the directions. You may also want to create an extra activity or reading library for the ones who finish early before it is time to switch workstations.

Then, decide if your stations are stable or portable. Next step, decide if you are choosing your leaders to start and then rotate. Then decide how much time are you giving them. In our study the students had 7 to 10 minutes depending on the activity and they rotated clockwise. We did not want to give them too much time to be bored or wonder around the classroom. Then prepare and label your baskets or your areas. Next, prepare, revise and complete your workstations. Next, deliver the workstations with your students. Asses, revaluate, modify and deliver again as needed. We also recommend you revise your workstations at least each semester or every academic year because student change and or classes too. For instance, you may have a great class working on Station A as an example but your class 2 does not work well with those directions.

As the activities on those workstations are infinitive and every professor can adapt or create their own according to their personal goals and objectives, here we give you some specific ideas to get you started on them.

\subsection{Listening or auditory workstations}

At the beginning listening level, the teacher reads aloud vocabulary words and students repeat them, read aloud stories according to the students level, play Mexican loteria or bingo created by the teacher that uses class vocabulary words. For free templates, you can do a Google search under "bingo creator" or "bingo generator." For a full list of songs and 
other resources at the beginning level see Chavez (2017a), p. 135. Elementary children can also listen to prerecorded stories at their level as many times their school libraries have leveled readers.

At the intermediate listening level, the students could do listening activities related to topic covered in classes like music, audio books, read aloud books, etc." For a full list of songs and other resources at the intermediate level see Chavez (2017a), p. 134-137. At the advanced listening level, students could listen to music in the target language, see short episodes on cartoons or movies, partners reading aloud while the other listens and listen to the news in the target language. Also for a full list of songs and more resources at the advanced level, see Chavez (2017a), p. 134-137.At the advanced plus level the students could do any of the above activity plus conversations and watch full movies in the target language.

\subsection{Speaking}

At the beginning level of speaking, students can practice the following items. They can describe orally a picture, an image from a book, read aloud vocabulary words from class, read aloud high frequency words to a partner, do a story mapping with guidance, use some already made conversational dialogs form the web like Google. At the intermediate level students may do story mapping with guidance, read aloud a story to a partner or group, drama center. At the advanced level, student could retell a story to a friend or group, read aloud short stories to a partner or to a group, drama center, invite important community members to talk about different topics that correlate with your curriculum, speak about different Hispanic celebrations in the US. Talk about Hispanic traditions, food, music, countries who speak the language. See Figures 10 and 11 for more information.

At the advanced plus level, the students can do all of the above activities plus have conversations regarding vocabulary covered in class, read in a book or heard in a song or short video, invite important community members to talk about different topics that correlate with your curriculum. They could also talk about Hispanic traditions, food, music, countries who speak the language. See Figures 10 and 11 for more information.

\subsection{Reading}

At the beginning level of reading, the students can read syllabus cards, vocabulary cards, high frequency words on level, read short stories with short sentences, read to a partner or group, reading their own writing, do level reader reading according to students level and interest. You can also do a story mapping with guidance. You can find them by doing a simple Google search in the web or with a visit to your school or local library. At the intermediate level of reading students can read headings in newspapers or news online website, read short stories to a partner or group, read easy books and intermediate books. Ideally, they should be by interest or by level of the students.

At the advanced level of reading students can read silently, read to a partner o group, read chapter books related to their interests and levels of the student, talk about Hispanic celebrations in US, MX and other Latin American countries. At the advanced plus level of speaking the students can do all of the above plus speak to a partner about it, read chapter books by interests and level, take virtual trips, talk about Hispanic celebrations in US, MX and other Latin American countries. Also, if the students know how to use the computer, web and have parental permission to use the internet, they can also use Spanish reading website stories for free. See Figures 10 and 11 for more ideas.

\subsection{Writing}

At the beginning level of writing students can do partner dictation, writing one-word descriptions about a picture, story, or event in a chapter book or class objective covered in class, you can also do a Google search on books with premade topic ideas. You can also do a story mapping with guidance. At the intermediate level of writing students can describe items in classroom, talk to partner about your writing and share their writing aloud. At the advanced level of writing, students can write short stories or ending to stories, describe family members, write about Hispanic celebrations in US, MX and other Latin American countries. At the advanced plus level of writing students can do all of the above activities plus collect stories in classroom booklets using staples, write about Hispanic celebrations in US, MX and other Latin American countries. If students already know how to type, they can also use the computer writing station using Word documents. See Figures 10 and 11 for more information.

\subsection{Story Mapping}

Story mapping can be done at all levels K-12, college level and beyond college for reading, listening, speaking and writing activities. It can be done before, during or after we hear or read a story. They can be done individually, with partner or groups or with the class (ReadingRockeckts.org, 2019). You can also do a Google search regarding this topic for ready templates for free or for purchase. A very simple one is the one that includes the main character, a place where it happened, a problem and a solution. For the more advanced ones you can add more things to the map like the time of event or events, additional characters like the antagonist, their characteristics, etc. They could also either retell 
or rewrite a different ending to their stories depending on their levels and interests. For the ones already able to use a computer, they can also write their mapping on computer.

\section{Grades K-12 Standards}

\subsection{Elementary Schools in Texas, Grades K-5}

In Texas, USA, Spanish language arts teachers need to know and implement the Texas Essential Knowledge and Skills (TEKS) for Spanish Language Arts, Reading, and English as a Second Language Subchapter A according to the Texas Education Agency or TEA (TEA.Texas.Org, 2019a; Solis, 2012). This happens in grades K-12. Those strands include listening, speaking, reading writing and research. The Houston Independent School District in Texas implement those standards and it is one of the biggest district in Texas and in the USA.

\subsection{Middle Schools in Texas, Grades 6-8}

In Texas, Spanish Language Arts and Reading teachers for middle school also need to include and implement seven areas of the TEKS that include listening, speaking, reading and writing (TEA.Texas.Org, 2019b).

\subsection{High Schools in Texas, Grades 9-12}

In Texas, Spanish teachers in high school also need to know and implement the TEKS also include listening, speaking, reading and writing among other skills (TEA.Texas.Org, 2019c).

\section{College Level Standards}

The standards for Spanish language arts at the college level may vary according to the department and college or university. There is more freedom than in grades K-12. According to Chavez (2017a) the levels in Spanish at the college level can be measured using several standards. Those may include the following: ACTFL, the Common European Framework of Reference (CEFR), Fairclough et al. (2010) and others.

6.1 ACTFL (American Council on the Teaching of Foreign Languages) is mostly used in the United States. It has four levels: novice, intermediate, advanced and superior.

6.2 The CEFR is mostly used in Europe and has three main levels: basic user, independent user and proficient user.

\section{Recommendations to improve college success rates and student retention}

7.1 How to increase academic success in Spanish classes at the college level to decrease FX or Failing grades due to attendance? Here we have three different tables with information regarding this matter. The Figure 12 is about preparation before the semester starts, Figure 13 is related to during the semester activity from the instructor and Figure 14 is related to the end of the semester work. However, many of those recommendations are done outside class.

\section{Beyond college or job related workstations}

As with the other workstations, the ones done in work sites also still need more scientific research. As of now, there is not reported effect on productivity either positively or negatively Ojo et al. (2018).

\section{Conclusions}

We believe that literacy workstations in language arts support teaching in modern days. They support attendance and retention rates, they may helpincrease academic success rates, they help to increase vocabulary rates and they may support the development of social skills. However, we also agree that more research must be done with bigger populations to make sure we are using the best teaching tools and resources for our students. Here we provided some ideas to use with literacy language arts workstations with listening, speaking, reading and writing at all levels in teaching grades K-12 and at the college level for Spanish classes. We hope that more teachers, researchers and administrators get motivated to do more research and implement workstations in their classroom beyond the language arts classes.

\section{Tables and Figures}


Figure 1: Level of Students from Chavez (2019a), p. 1 based on Fairclough et al. (2010)

\begin{tabular}{lll}
\hline Vocabulary Words by Level & $\begin{array}{l}\text { Levels Based on Fairclough et al. } \\
(2010)\end{array}$ & Number of Approximate Wor \\
\hline 1 & Beginning Level A & $0-3500$ \\
2 & Intermediate Level B & $3501-5000$ \\
3 & Advanced Level C & $5000+$ \\
4 & Advanced Level +D & $5000+$ \\
\hline
\end{tabular}

Figure 2:Level of Students Based on PreTest Results Based on Chavez (2019a)

\begin{tabular}{lllll}
\hline $\begin{array}{l}\text { Vocabulary Words Based } \\
\text { on Fairclough et al. }\end{array}$ & Level Number: & $\begin{array}{l}\text { Percentage: } \\
100 \%\end{array}$ & $\begin{array}{l}\text { Number } \\
\text { Students: } 36\end{array}$ & of \\
$(2010)$ & 1 & & 36 \\
\hline $0-3500$ & 2 & $89 \%$ & 4 \\
$3501-5000$ & 3 & $11 \%$ & 0 \\
$5000+$ & 4 & $0 \%$ & 0 \\
$5000+$ & $0 \%$ & $0 \%$ & \\
\hline
\end{tabular}

Figure 3: Level of Students Based on Post Test Results

\begin{tabular}{|c|c|c|c|c|c|c|}
\hline \multicolumn{2}{|c|}{$\begin{array}{l}\text { Vocabulary Words } \\
\text { Based on Fairclough et } \\
\text { al. (2010) }\end{array}$} & Level Number & \multicolumn{2}{|c|}{$\begin{array}{l}\text { Percentage } \\
100 \%\end{array}$} & \multicolumn{2}{|c|}{ Number of Students: 32} \\
\hline \multicolumn{2}{|c|}{$0-3500$} & 1 & \multicolumn{2}{|l|}{$81 \%$} & \multicolumn{2}{|l|}{26} \\
\hline \multicolumn{2}{|l|}{$3501-5000$} & 2 & \multicolumn{2}{|l|}{$19 \%$} & \multicolumn{2}{|l|}{6} \\
\hline $5000+$ & & 3 & \multicolumn{2}{|l|}{$0 \%$} & \multicolumn{2}{|l|}{0} \\
\hline $5000+$ & & 4 & \multicolumn{2}{|l|}{$0 \%$} & \multicolumn{2}{|l|}{0} \\
\hline \multicolumn{7}{|c|}{ Figure 4:Lexical Survey Pre Test Results Based on Chavez (2019a), p. 1} \\
\hline & $\%$ Averag & $\begin{array}{l}\text { Number of } \\
\text { Questions }\end{array}$ & $\begin{array}{l}\text { Average } \\
\text { Vocabulary } \\
\text { Words } \\
\end{array}$ & $\begin{array}{l}\text { Highest } \\
\text { Score }\end{array}$ & $\begin{array}{l}\text { Lowest } \\
\text { Score in } \\
\text { Vocabulary }\end{array}$ & $\begin{array}{l}\text { Pearson } \\
\text { Correlation } \\
\mathrm{r}=.94\end{array}$ \\
\hline $\begin{array}{l}\text { Survey } \\
\mathrm{N}=27\end{array}$ & 129 & 25 & 1452 & 4000 & 330 & 0.94 \\
\hline $\begin{array}{l}\text { Survey } 2 \\
N=27\end{array}$ & 50 & 50 & 2370 & 4100 & 0 & 0.94 \\
\hline
\end{tabular}

Figure 5:Lexical Surveys Post Test Results

\begin{tabular}{llllllll}
\hline $\begin{array}{l}\text { Lexical } \\
\text { Surveys } \\
\text { Post Tests }\end{array}$ & $\begin{array}{l}\% \\
\text { Average }\end{array}$ & \# Questions & $\begin{array}{l}\text { Average } \\
\text { Vocabulary } \\
\text { Words }\end{array}$ & $\begin{array}{l}\text { Highest } \\
\text { Score }\end{array}$ & $\begin{array}{l}\text { Lowest } \\
\text { Score in } \\
\text { Voc. } \\
\text { Words }\end{array}$ & $\begin{array}{l}\text { Pearson } \\
\text { Correlation } \\
\text { R=.93 }\end{array}$ & $\begin{array}{l}\text { Average } \\
\text { Time }\end{array}$ \\
\hline $\begin{array}{l}\text { Survey } 1 \\
\text { N=32 }\end{array}$ & 54 & 25 & 2756 & 4700 & 1000 & 0.93 & $\begin{array}{l}9: 57 \\
\text { Survey } 2 \\
\text { N=32 }\end{array}$ \\
\hline
\end{tabular}


Figure 6: Workstations Survey Pretest Results Based on Chavez (2019), p. 1

\begin{tabular}{|c|c|c|}
\hline 1 & Social Skills & $\begin{array}{l}25 \% \text { of Students Said that Workstations Allow me to work one on one With } \\
\text { Professor }\end{array}$ \\
\hline 2 & Academic Skills & $\begin{array}{l}25 \% \text { of Students Said that Workstations Give me leadership skills and support } \\
\text { Language learning }\end{array}$ \\
\hline 3 & Best Workstation & $47 \%$ of Students Chose Listening Workstations as the Best \\
\hline 4 & Mixed Classes & $\begin{array}{l}\text { 53\% of Students Identified Themselves as Students of Spanish as Second Language } \\
\text { (L2) }\end{array}$ \\
\hline \multicolumn{3}{|r|}{ Figure 7: Workstations Post Test Results } \\
\hline \multicolumn{2}{|c|}{ Social and Personal } & $\begin{array}{ll}\text { Academic Skills } & \text { Best Workstation }\end{array}$ \\
\hline \multicolumn{2}{|c|}{$\begin{array}{ll}50 \% \text { improved social } & \text { skills } \\
\text { and selfsteem } & \\
19 \% \text { became } & \text { more } \\
\text { responsible } & \end{array}$} & $\begin{array}{ll}32 \% \text { less intimidating } & 40 \% \text { Listening } \\
\text { environment } & 28 \% \text { Oral } \\
16 \% \text { improved } & 19 \% \text { Writing } \\
\text { vocabulary learning } & \\
\begin{array}{l}13 \% \text { improved their } \\
\text { leadership skills }\end{array} & \\
\end{array}$ \\
\hline
\end{tabular}

Figure 8: Attendance and Retention Success Rate End of Semester

\section{Attendance End of Semester}

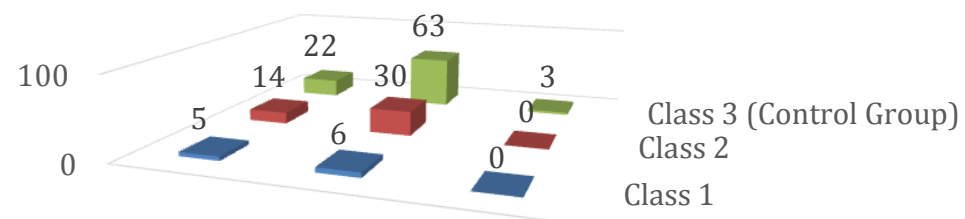

\# of Students Absences

Percentage FX Grades

- Class $1 \square$ Class $2 \square$ Class 3 (Control Group)

Figure 9: Academic Success Rate End of Semester

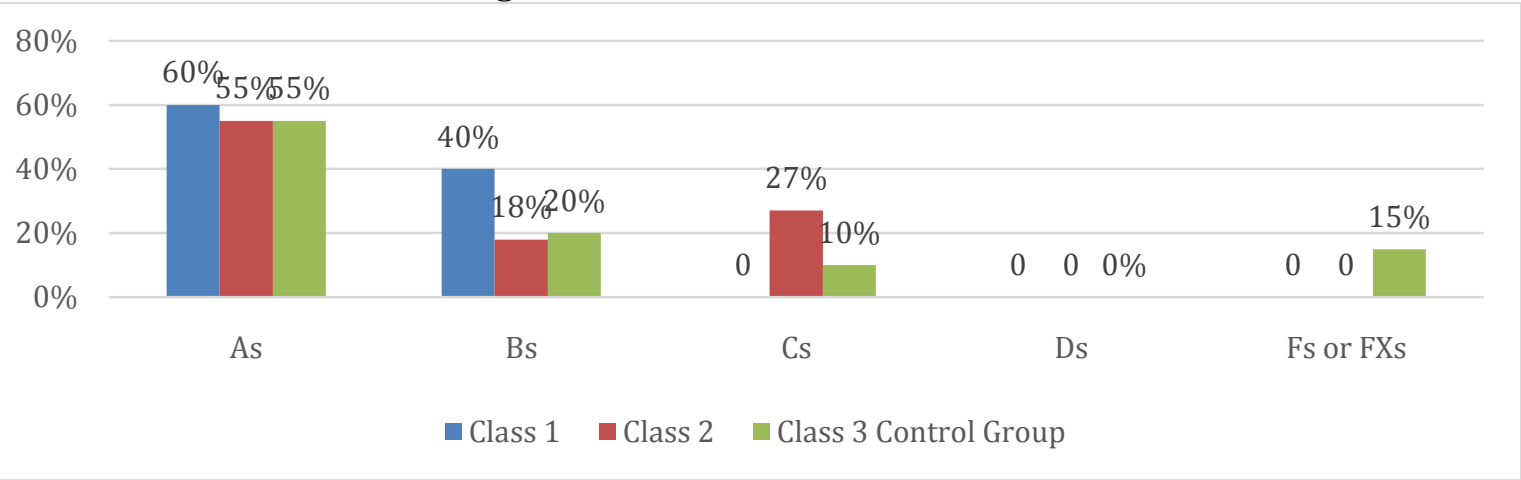




\section{Figure 10: Hispanic Celebrations in US Adapted from HHMC (2018)}

Month

Year

January $\quad$ New Year (1), 3 Kings Day MX\& US (6), Juan Gabriel's Birthday MX (7)

February

Día de la Candelaria Virgin MX (2) Shakira'sBirthday Colombia (2), International Mother'sLanguage

March Holy WeekReligious MX and US (varies), César Chávez' Birthday US(31) Day US (21)

April

Holy Week MX and US (15-19 varies), Selena Quintanilla's Birthday US (16),

May $\quad$ Cinco de Mayo MX (5), Mother’s Day MX \& US (10), E. Iglesias’ Birthday (8)

June $\quad$ Father's Day MX and US (16)

July $\quad$ American Independence Day USA (4), Jennifer Lopez’ Birthday PR \& US (24)

August Virgin Mary Entrance to Heaven MX (15), Lucero's Birthday MX (30)

September

Gloria Estefan's Birthday Cuba \& US (1), E.Derbez' Birthday MX \& US (2), Mexican Independence $(15,16)$, Hispanic Heritage Month Starts US, (15-30), Teach Spanish Day US (30)

October

Day of the Race/Christopher's Columbus Day MX, US \& Spain (12),

Hispanic Heritage Month US (1-15), Day of the Dead Preparation MX (31)

November

Day of the Dead (1), Day of the Dead All Saints' Day (2), Native American Month Celebration US (All Month)

December

Virgin of Guadalupe Religious MX \& US (12), Las Posadas (Preparation for Christmas Religious(1624), Christmas (24), Christmas Religious (25), New Year's Eve (31)

Figure 11: Hispanic Traditions, Music and Food

Religious and Weddings, baptisms, Quinceañeras and Quinceañeros

Cultural:

Countries where Argentina, Bolivia, Chile, Colombia, Costa Rica, Cuba, DominicanRepublic,

Spanish is Spoken: Ecuador, El Salvador, Equatorial Guinea, Guatemala, Honduras, Mexico,

Nicaraga, Panama, Paragua, Peru, Spain, Uruguay, Venezuela and the US

Hispanic Music: $\quad$ Mariachi, cumbia, salsa, bachata, banda, regional mexicana etc.

HispanicFood: $\quad$ Corn tortillas, flour tortillas, buñuelos, tamales, rosca de reyes, mole poblano, tacos, etc.

FamilyMembers Mamá, papá, hermano, hermana, tío, tía, abuelita, abuelito, etc.

Figure 12: Before Semester Starts or Academic Year Starts

Make class materials or sources cheap or free

Prevent students' isolation-how will you do this?

How will you provide intervention programs or resources like remedial instruction, extra credit etc.

Where is the at risk personnel to reach out to at risk students? Is it available?

What extracurricular participation is available on campus like student organizations?

How will you measure academic success in your class?

Check the syllabus and calendar to make sure they are updated for the semester. Do they include everything you need?

Any other areas I need to include: 
Figure 13:During the Semester or Academic Year

Identify at risk students: first generation, work, family, level of knowledge etc.

Help to improve students' self-esteem, college adjustment and family support and resources to prevent isolation.

Assist with motivation and self-control and help them with school expectations

Providehigh impact learning and or personalized instruction: tutoring, workstations, office hours, etc.

Offer many opportunities for success in your class like extra credit etc.

Have at least two individual conferences with each student one at the beginning of the semester and one at the end. If needed, have a third conference in between.

Do academic statistics after each exam, how can you improve them?

Measure academic success in your class with end of semester statistics

Do you need any calendar or syllabus changes?

Are any other reasons not listed here that I want to add:

Figure 14:After the Semester Ends or Academic Year Ends

What is available for extracurricular activities? If nothing is available, consider creating a club or organization.

Make sure students have clear expectations or college path of college for their major.

Do academic success statistics at the end of the semester and compare them?

How can you improve your teaching methods, materials, workstations, etc.?

Did your calendar or lesson plan work? If not, make necessary changes.

Did your syllabus work? If not make necessary changes.

Are there any other reasons not listed here that you want to add:

\section{References}

Abou-Sayed, Y. (2011). Using small groups and workstations: from chaotic to constructive. Texas Child Care Quarterly. Winter. ChildCareQuarterly.com 35.3, 1-4 [Online] Available: https://www.childcarequarterly.com/pdf/winter11_smallgroups.pdf(November 18, 2019)

ACTFL Guidelines, (2012). Spanish. [Online] Available: https://www.actfl.org/publications/guidelines-andmanuals/actfl-proficiency-guidelines-2012/spanish (November, 15, 2019)

Beaudrie, S. M. and Fairclough, M. (2012). Spanish as a Heritage Language in the United States: The State of the Field. Georgetown: University Press.

CEFRL, (2018). Common European Framework of Reference for Languages (CEFR): Spanish Levels. [Online] Available: https://www.coe.int/en/web/common-european-framework-reference-languages (November 15, 2019)

Chavez, Y. (2019a). College Workstations: How Do Spanish Heritage Learners (HLLs) Empower Students of Second Language (L2). Scholarship of Teaching and Learning Colloquium. San Jacinto College Central. April 15. Pasadena, Texas.

Chavez, Y. (2019b). ¿Cómo enriquecen los hablantes de herencia (HH) a los estudiantes de español como L2(EEL2) en las clases de español usando estaciones de lenguaje? The American Association of Spanish and Portuguese. San Diego California, USA.

Chavez, Y. (2017a). El léxico español de los estudiantes de herencia de secundaria en Houston. Doctoral Dissertation. University of Houston. Houston, TX.

Chavez, Y. (2017b June). Attendance and Homework Do Matter in Spanish as Second Language Classes. American International Journal of Contemporary Research. 7.2. 37-38. [Online] Available: http://www.aijcrnet.com/journals/Vol_7_No_2_June_2017/6.pdf (November 18, 2019)

Deussen, et. al. (2008). What Teachers Should Know About Instruction for English Language Learners. For Research, Evaluation, and Assessment. [Online] Available:

https://educationnorthwest.org/sites/default/files/resources/what-teachers-should-know-about-instruction-forells.pdf(November 13, 2019)

Falcon, L. (2019). Breaking down barriers: first generation college students and college success. Vol. 10, Number 6. P. 1 [Online] Available: https://www.league.org/innovation-showcase/breaking-down-barriers-first-generationcollege-students-and-college-success 
Fisher, E. (2014). Using Centers and Stations to Teach World Language. CalicoSpanish.com. [Online] Available: https://calicospanish.com/using-centers-and-stations-to-teach-world-language/(November 18, 2019)

Fishman, T. D. et al., (2017). Success by design: Improving outcomes in American higher education. [Online] Available: https://www2.deloitte.com/insights/us/en/industry/public-sector/improving-student-success-inhigher-education.html (November 15, 2019)

HHMC (2018). Hispanic Celebrations in US. San Jacinto College-Central. Pasadena, TX. USA.

Hilberg et. al. (2003). Designing Effective Activity Centers for Diverse Learners: a guide for teachers atall grade levels and for all subject areas. Center for Research on Education, Diversity and Excellence. [Online] Available http://manoa.hawaii.edu/coe/crede/wp-content/uploads/Hilberg_et_al_20031.pdf (November 15, 2019)

Hundrieser, J., and Dautcher, T. (March-April 2018). The complexities of student success. Vol. 26, Number 2. P. 1. [Online] Available: https://agb.org/trusteeship-article/the-complexities-of-student-success/ (November 15, 2019)

McAughtire, D., (08, June, 2016). 10 strategies to increase student retention. [Online] Available:

https://www.unit4.com/blog/2016/06/10-ways-to-increase-student-retention (November 15, 2019)

Ojo, S. et al. (2018). The Impact of Active Workstations on Workplace Productivity and Performance: a Systematic Review. [Online] Available:

https://www.researchgate.net/publication/323441593_The_Impact_of_Active_Workstations_on_Workplace_P roductivity_and_Performance_A_Systematic_Review(November 15, 2019)

ReadingRockets.org. (2019a). Literacy Centers. [Online] Available: https://www.readingrockets.org/article/literacycenters(November 15, 2019)

ReadingRockects.org, (2019b). Story Mapping. [Online] Available: https://www.readingrockets.org/strategies/story_maps(November 15, 2019)

Solis, A. (2012). Teaching Spanish in Texas Schools. Elementary.[Online] https://www.idra.org/images/stories/Teaching_Spanish_in_Texas_Schools.pdf(November 15, 2019)

Tea.Texas.Gov. (2019a).Elementary. [Online] Available: https://tea.texas.gov/sites/default/files/ch128a-one_SBOE_rev.pdf(November 15, 2019)

Tea.Texas.Gov. (2019b) TEKS Standards for Middle School.[Online] Available: https://tea.texas.gov/sites/default/files/Cap\%C3\%ADtulo\%20128\%20Artes\%20del\%20Lenguaje\%20y\%20Lec tura\%20en\%20espa\%C3\%B1ol_6_Adoptado\%20en\%202017_June\%20192019.pdfhttps://tea.texas.gov/sites/default/files/ch128b-one_SBOE_rev.pdf(November 15, 2019)

Tea.Texas.Gov. (2019c). TEKS Standards for High School. [Online]Available: https://tea.texas.gov/sites/default/files/ch128c-one_SBOE_rev.pdf(November 15, 2019)

Willow Creek Elementary (WCE), (2019). Elementary Workstations. [Online] Available: https://wces.tomballisd.net/apps/pages/index.jsp?uREC_ID=498854\&type=u\&pREC_ID=736453(November $15,2019)$

Worthy, J. et. al (January, 2015). What Are the Rest of the Students Doing? Literacy Work Stations in Two First-Grade Classrooms. National Council of Teachers of English. Language Arts.Vol. 92.3. [Online] Available: https://www.ncte.org/library/NCTEFiles/Resources/Journals/LA/0923-jan2015/LA0923What.pdf (November $18,2019)$ 